\title{
PROGRAM PEMBERDAYAAN KELUARGA MISKIN UNTUK MENINGKATKAN KESEJAHTERAAN MASYARAKAT DESA KARAMAT MULYA MELALUI PENGUATAN KELOMPOK USAHA BERSAMA DINAS SOSIAL JAWA BARAT
}

\author{
Iis Kurnia Nurhayati ${ }^{1}$, Marheni Eka Saputri ${ }^{1}$, Agus Aprianti, ${ }^{1}$ dan Ira Wirasari ${ }^{2}$ \\ ${ }^{1}$ Fakultas Komunikasi dan Bisnis, Telkom University \\ ${ }^{2}$ Fakultas Ilmu Kreatif, Telkom University \\ E-mail: iiskurnian@gmail.com
}

\begin{abstract}
ABSTRAK. Salah satu daerah di Jawa Barat yang merupakan bagian dari daerah dengan penyandang masalah kesejahteraan sosial adalah Desa Karamat Mulya di Soreang Kabupaten Bandung.Hal ini yang ditemui bahwa masyarakat di Desa Karamat Mulya Soreang Kabupaten Bandung sebelum mendapatkan bantuan dari pemerintah melalui Dinas Sosial Provinsi Jawa Barat kehidupan ekonomi masyarakat cukup memprihatinkan, karena penghasilan yang diperoleh di bawah kecukupan. Untuk menanggulangi kemiskinan, pemerintah telah menggulirkan berbagai bantuan atau insentif berupa dana maupun program. Melalui Kelompok Usaha Bersama (KUBE) bagi kaum miskin merupakan salah satu program yang dikembangkan pemerintah melalui dinas sosial.Melalui KUBE diharapkan masyarakat miskin dapat mengembangkan potensinya sehingga dapat meningkatkan taraf hidup keluarga. Untuk mengatasi soal kemiskinan, tidak bisa lagi dilakukan secara perorangan atau hanya sekedar pertolongan sesaat, tapi harus sistematik dan berkesinambungan. Untuk itu diperlukan komitmen yang tulus dan tindakan kolektif dari semua pihak pemerintahan, kalangan swasta, akademisi dan masyarakat miskin itu sendiri. Pendekatannya pun harus bersifat holistik.Salah satu Tridharma Perguruan Tinggi adalah pengabdian pada masyarakat. Oleh karena itulah, tim dosen dari Fakultas Komunikasi dan Bisnis dan Fakultas Industri Kreatif Telkom University berkomitmen dan bertindak dengan tulus untuk untuk mengatasi soal kemiskinan di Indonesia khususnya di Jawa Barat dengan memberikan pelatihan dan pemberian teknologi tepat guna untuk masyarakat sasar di Desa Karamat Mulya Soreang.
\end{abstract}

Kata kunci: Kesejahteraan Sosial, Kelompok Bersama, Pengembangan Produk

ABSTRACT. One of the areas in West Java with social welfare problems is Karamat Mulya Village in Soreang, Bandung Regency. The economy of the community is alarming since the income rate of the villagers is below adequacy. To overcome poverty, the government has rolled out various assistance or incentives in the form of funds and programs. The Joint Business Group (KUBE) for the poor is one of the programs developed by the government through social services. Through KUBE, it is hoped that the poor can develop their potential so that they can improve family living standards. To overcome the problem of poverty, it can no longer be done individually and in short time, it must be systematic and sustainable. For this reason, sincere commitment and collective actions from all parties of government, the private sector, academics and the poor themselves are needed. The approach must also be holistic. One of the Three Principles of Higher Education is community service. Therefore, the team of lecturers from the Faculty of Communication and Business and the Faculty of Creative Industry Telkom University committed and acted sincerely to overcome the problem of poverty in Indonesia, especially in West Java by providing training and appropriate technology to targeted communities in Karamat Mulya Village, Soreang.

\section{PENDAHULUAN}

Data kesejahteraan sosial menurut Kementrian Sosial republik Indonesia menunjukkan bahwa daerah dengan penyandang masalah kesejahteraan sosial tertinggi di Indonesia adalah Jawa Barat dengan jumlah 40.982, sedangkan daerah dengan penyandang masalah kesejahteraan sosial terendah di Indonesia adalah Maluku Utara dengan jumlah 20. Masalah kesejahteraan sosial yang dimaksud adalah ketidakmampuan dalam memenuhi kebutuhan dasar makan dan non makanan (pengeluaran) yang dikonversi dengan nilai uang, sehingga rata-rata pengeluaran perkapita perbulan di bawah garis kemiskinan. Berikut adalah statistis data penyandang masalah kesejahteraan sosial berdasarkan Kepmensos Nomor 178/ HUK/2016.

Salah satu daerah di Jawa Barat yang merupakan bagian dari daerah dengan penyandang masalah kesejahteraan sosial adalah Desa Karamat Mulya di Soreang Kabupaten Bandung. Hal ini yang ditemui bahwa masyarakat di Desa Karamat Mulya Soreang Kabupaten Bandung sebelum mendapatkan bantuan dari pemerintah melalui Dinas Sosial Provinsi Jawa Barat kehidupan ekonomi masyarakat cukup memprihatinkan, karena penghasilan yang diperoleh di bawah kecukupan. Untuk menanggulangi kemiskinan, pemerintah telah menggulirkan berbagai bantuan atau insentif berupa dana maupun program, seperti Program Penanggulangan Kemiskinan Perkotaan (P2KP), Bantuan Langsung Tunai (BLT), Bantuan Beras Untuk Rakyat Miskin(Raskin), Program Nasional Pemberadayaan Masyarakat (PNPM) Mandiri, Pengembangan Usaha Ekonomi Produktif (UEP) dan Usaha Kesejahteraan Sosial (UKS) melalui Kelompok Usaha Bersama (KUBE) bagi kaum miskin merupakan salah satu program yang dikembangkan pemerintah melalui dinas sosial. Pengembangan Lembaga Keuangan Mikro KUBE Sejahtera yang didirikan di setiap desa miskin/ terpencil untuk memfasilitasi modal usaha bagi KUBE-KUBE kaum miskin: bekerjasama dengan PINBUK sejak thn 2003. Melalui KUBE diharapkan masyarakat miskin dapat mengembangkan potensinya sehingga dapat meningkatkan taraf hidup keluarga.

Di samping itu aparat pemerintah, secara perorangan maupun kelembagaan, juga berperan aktif memberikan bantuan yang ditujukan bagi rakyat miskin agar keluar dari berbagai kesulitan. Namun 
Tabel 1. Data Statistik Penyandang Masalah Kesejahteraan Sosial Berbasis Panti

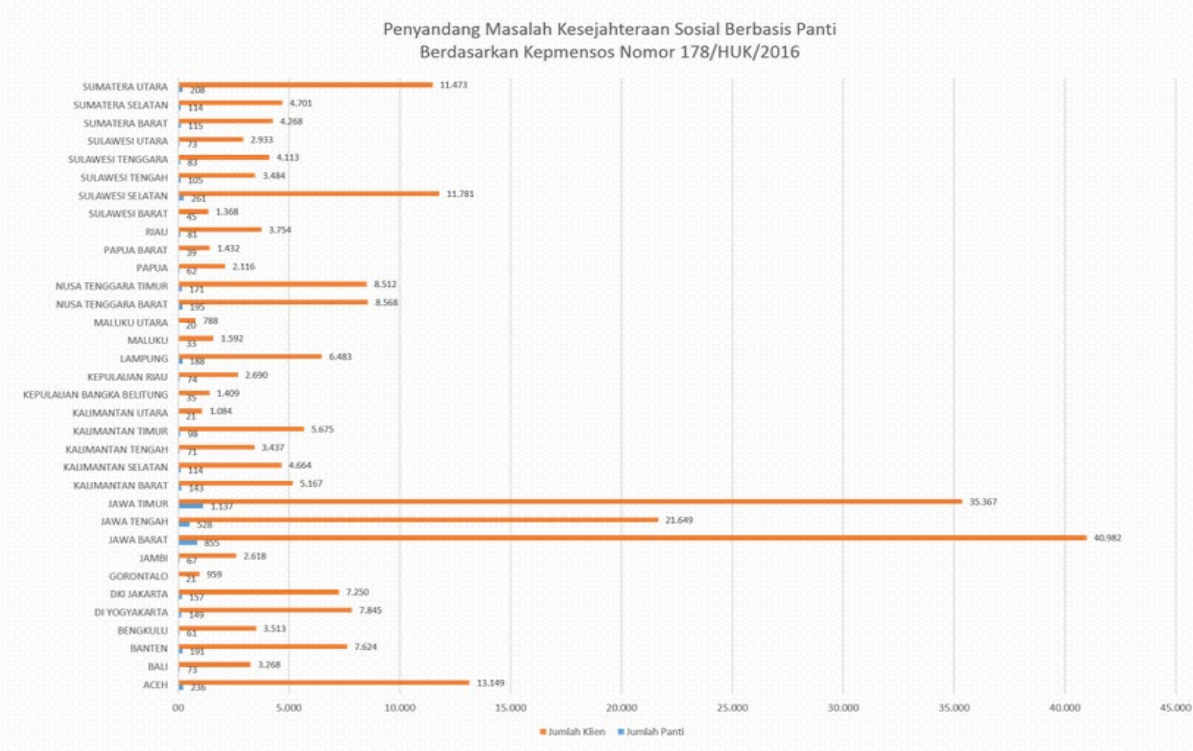

Sumber (https://www.kemsos.go.id/content/data-kesejahteraan-sosial-0)

model penanggulangannya cenderung menggunakan pendekatan karitatif (kedermawanan) yang memiliki berbagai kelemahan yaitu membuat mereka ketergantungan terhadap bantuan, bersikap apatis dan menampilkan semangat untuk malas berswadaya. Untuk mengatasi soal kemiskinan, tidak bisa lagi dilakukan secara perorangan atau hanya sekedar pertolongan sesaat, tapi harus sistematik dan berkesinambungan. Untuk itu diperlukan komitmen yang tulus dan tindakan kolektif dari semua pihak: pemerintahan, kalangan swasta, akademisi dan masyarakat miskin itu sendiri. Pendekatannya pun harus bersifat holistik.

Desa Karamat Mulya merupakan desa binaan Dinas Sosial Provinsi Jabar dengan karakteristik mata pencaharian penduduk berupa pertanian dan industri jahit perumahan. Ketenaga kerjaan penduduk Desa Karamat Mulya dengan jumlah penduduk yang bekerja sebanyak 1.664 orang, jumlah penduduk yang mencari kerja sebanyak 187 orang dan jumlah penduduk yang tidak bekerja atau menganggur sebanyak 262 orang (21\%). Adapun tingkat pendidikan masyarakat Desa karamat Mulya mayoritas adalah tamat SD sederajat dengan jumlah 642 orang laki-laki dan 671 orang perempuan, dan lulusan SMP sederajat berjumlah 689 laki-laki dan 703 perempuan. Adapun permasalahan yang dihadapai menyangkut masyrakat di desa Karamat Mulsa Soreang Kabupaten Bandung secara garis besarnya meliputi:

1. Jumlah masyarakat miskin cenderung tidak menurun

2. Peluang usaha yang ada relatif terbatas

3. Belum optimalnya usaha ekomomi produktif

4. Keterbatasan akses pasar bagi kelompok usaha

Dari masalah yang teridentifikasi, dapat dirumuskan masalah yang hendak diselesaikan dalam pengabdian pada masyarakat adalah bagaimana memberdayakan masyarakat miskin di desa tersebut melalui usaha ekonomi produktif.

\section{METODE}

Kegiatan pengabdian pada masyarakat ini ditujukan untuk memberikan pengetahuan dan keterampilan kepada masyarakat sasar yang dikategorikan sebagai Keluarga Miskin untuk Meningkatkan Kesejahteraan Melalui Penguatan Kelompok Usaha Bersama Dinas Sosial Propinsi Jawa Barat. Adapun metode yang digunakan dalam kegiatan ini adalah pelatihan dengan teknik presentasi, demonstrasi, dan praktik secara individu maupun kelompok dan Penyusunan sistem informasi dan teknologi lain yang dibutuhkan masyarakat

a. Metode presentasi

Metode ini digunakan untuk menyampaikan beberapa hal yang berkaitan dengan bahasa persuasif untuk dicantumkan dalam kemasan baik bahasa verbal maupun nonverbal, manfaat, fungsi, bahan alat, bagaimana cara membuat kemasan produk, mulai dari awal sampai akhir.

b. Metode Demonstrasi

Metode ini digunakan untuk menunjukkan contoh produk/model yang dihasilkan dari pelatihan yang diberikan, misalnya contoh kemasan yang telah diberi teknik persuasif berupa slogan atau tagline yang digunakan dalam kemasan produk. Metode ini digunakan untuk menunjukkan atau menampilan proses pembuatan desain kemasan produk kepada masyarakat Desa Karamat Mulya Soreang. Diharapkan dengan adanya metode ini para peserta dapat mempraktikkan langsung membuat desain kemasan sesuai dengan prosedur pembuatan karya .

c. Metode Praktik

Metode ini dilakukan untuk melatih masyarakat 
sasar di desa Karamat Mulya peserta kegiatan ini khususnya petani dan para pelaku bisnis rumahan dan pengusaha kecil dan menengah di desa tersebut. Metode ini dilakukan agar petan pelaku bisnis rumahan dan pengusaha kecil dan menengah di desa, tersebut mempunyai pengalaman langsung tentang pembuatan kemasan produknya.

\section{Partisipasi Mitra dalam pelaksanaan program}

Partisipasi mitra yaitu Dinas Sosial Provinsi Jabar dalam pelaksanaan kegiatan pengabdian pada masyarakat ini saling melengkapi dengan dosen pelaksana kegiatan pengabdian pada masyarakat yang merupakan akademisi di perguruan tinggi dengan Tri Dharma yang dimilikinya. Adapun partisipasi dari mitra dapat dilihat dari bagan berikut ini

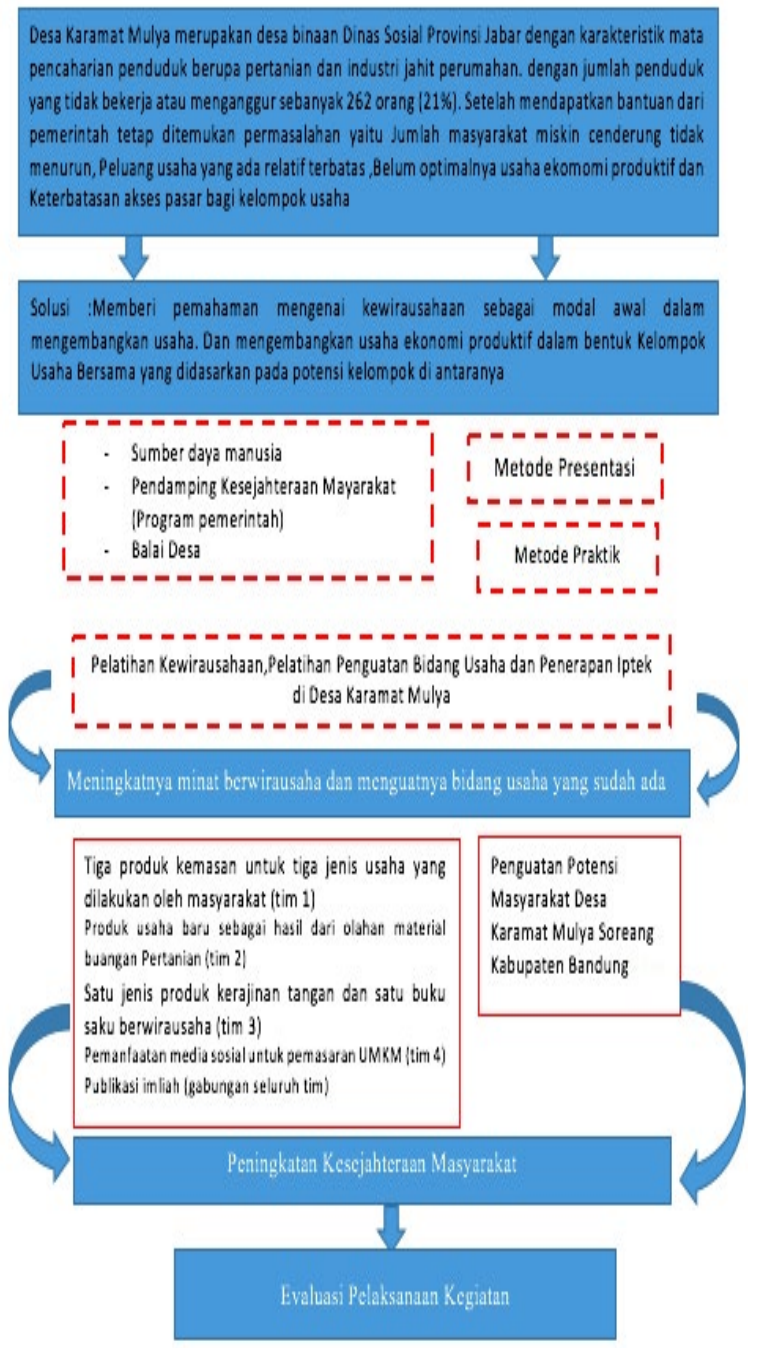

Gambar 1. Partisipasi Mita dalam Kegiatan Pengabdian Kepada Masyarakat

\section{HASIL DAN PEMBAHASAN}

Iptek yang ditransfer kepada peserta kegiatan Program Pemberdayaan Keluarga Miskin untuk Meningkatkan Kesejahteraan Masyarakat Desa Karamat Mulya Soreang Melalui Penguatan Kelompok Usaha Bersama Dinas Sosial Propinsi Jawa Barat ini adalah sebagai berikut :

\section{Pengolahan Limbah Kain Percak dan Pembuatan Produk Limbah Kain Percak}

Kerajinan tangan kain perca yang dilakukan menggunakan sisa hasil jahitan buruh jahit di Desa Kramat Mulya, Kec. Soreang. Kerajinan yang dilakukan menghasilkan 3 jenis produk antara lain: Gantungan Kunci, Bros Bunga dan Hiasan

1) Masyarakat sasar diajarkan cara memilih kain yang dapat digunakan sebagai bahan kerajinan. Masyarakat membuat pola Bunga dan Daun. Kegiatan ini dihadiri oleh sekitar 44 orang. Proses pembuatan membutuhkan waktu cukup lama terutama dalam pengenalan bahan / kain dasar yang biasa digunakan untuk kerajinan.

2) Masyarakat diajarkan dan diberikan praktek membuat kerajinan berbentuk Labu dan Daun. Serta Pembuatan Bunga Tulip dan Kuncup Bunga. Kegiatan ini dihadiri oleh 44 orang peserta.

3) Masyarakat diajarkan merangkai hasil karya tersebut menjadi sebuah produk. Dan produk yang dihasilkan adalah menjadi Gantungan Kunci, Bros dan Hiasan. Acara ini dihadiri sekitar 50 orang peserta. Dalam pelatihan ini juga dilakukan Loma Kreativitas yaitu Peserta diminta membuat produk dari Perca yang menarik dan palinhg kreatif akan dipilih 3 pemenang dari 50 peserta yang ada untuk diberikan apresiasi berupa Hadiah/ Doorprize.

4) Setelah itu masyarakat diajarkan perihal pembentukan organisasi, karena masyarakat pembuat kerajinan akan jadi tenaga pembuat sedangkan pengelola dilakukan oleh tim gabungan antara perwakilan Desa Kramat Mulya dan PKH Kecamatan Soreang yang terdiri dari 20 orang. Kegiatan ini dilakukan pada 31 Agustus 2018, setelah dilakukannya FGD untuk melihat potensi apa saja yang bias dikembangkan di desa ini.

\section{Pengemasan Produk}

Kemasan adalah desain kreatif yang mengaitkan bentuk, struktur, material, warna, citra, tipografi dan elemen-elemen desain dengan informasi produk agar produk dapat dipasarkan. Kemasan digunakan untuk membungkus, melindungi, mengirim, mengeluarkan, menyimpan, mengidentifikasi dan membedakan sebuah produk di pasar (Klimchuk dan Krasovec, 2006:33).

Menurut Kotler \& Keller (2009:27), pengemasan adalah kegiatan merancang dan memproduksi wadah atau bungkus sebagai sebuah produk. Pengemasan adalah aktivitas merancang dan memproduksi kemasan atau pembungkus untuk produk. Biasanya fungsi utama dari kemasan adalah untuk menjaga produk. Namun, sekarang kemasan menjadi faktor yang cukup penting sebagai alat pemasaran (Rangkuti, 2010:132).

Kemasan yang dirancang dengan baik dapat membangun ekuitas merek dan mendorong penjualan. Kemasan adalah bagian pertama produk yang dihadapi pembeli dan mampu menarik atau menyingkirkan pembeli. Pengemasan suatu produk biasanya dilakukan oleh 
produsen untuk dapat merebut minat konsumen terhadap pembelian barang. Produsen berusaha memberikan kesan yang baik pada kemasan produknya dan menciptakan model kemasan baru yang berbeda dengan produsen lain yang memproduksi produk-produk sejenis dalam pasar yang sama.

Banyak perusahaan yang sangat memperhatikan pembungkus suatu barang sebab mereka menganggap bahwa fungsi kemasan tidak hanya sebagai pembungkus, tetapi jauh lebih luas dari pada itu. Simamora (2007) mengemukakan pengemasan mempunyai dua fungsi yaitu:

1. Fungsi Protektif. Berkenaan dengan proteksi produk, perbedaan iklim, prasarana transportasi, dan saluran distribusi yang semua berimbas pada pengemasan. Dengan pengemasan protektif, para konsumen tidak perlu harus menanggung risiko pembelian produk rusak atau cacat.

2. Fungsi Promosional. Peran kemasan pada umumnya dibatasi pada perlindungan produk. Namun kemasan juga digunakan sebagai sarana promosional. Menyangkut promosi, perusahaan mempertimbangkan preferensi konsumen menyangkut warna, ukuran, dan penampilan.

Sedangkan menurut Kotler (1999:228), terdapat empat fungsi kemasan sebagai satu alat pemasaran, yaitu: 1) Self service. Kemasan semakin berfungsi lebih banyak lagi dalam proses penjualan, dimana kemasan harus menarik, menyebutkan ciri-ciri produk, meyakinkan konsumen dan memberi kesan menyeluruh yang mendukung produk.

2) Consumer offluence. Konsumen bersedia membayar lebih mahal bagi kemudahan, penampilan, ketergantungan dan prestise dari kemasan yang lebih baik.

3) Company and brand image. Perusahaan mengenal baik kekuatan yang dikandung dari kemasan yang dirancang dengan cermat dalam mempercepat konsumen mengenali perusahaan atau merek produk.

4) Inovational opportunity. Cara kemasan yang inovatif akan bermanfaat bagi konsumen dan juga memberi keuntungan bagi produsen.

Proses desain pada umumnya memperhitungkan aspek fungsi, estetik dan berbagai macam aspek lainnya, yang biasanya datanya didapatkan dari riset, pemikiran, brainstorming, maupun dari desain yang sudah ada sebelumnya. Dalam perancangan atau mendesain suatu kemasan produk dapat kita memperhatikan beberapa aspek dasar dalam menentukan kemasan produk itu sendiri, diantaranya daya tarik kemasan sangat penting guna tertangkapnya stimulusoleh konsumen yang di sampaikan ke produsen sehingga diharapkan konsumen tertarik pada produk tersebut. Menurut Wiryo (1999:10) daya tarik visual kemasan dapat digolongkan menjadi dua yaitu: daya tarik visual dan daya tarik praktis.

Daya Tarik Visual, Daya tarik visual mengacu pada penampilan kemasan atau lebel suatu produk mencakup warna, bentuk, merk/logo, ilustrasi, teks/tipografo, tata letak (Wirya, 1999:28-30).Warna adalah suatu mutu cahaya yang dapat dipantulkan darisuatu objek ke mata manusia. Warna terbagi dalam kategori terang (mudah), sedang, gelap (tua). Fungsi dari pemilihan warna :

1. Untuk identifikasi produk sehingga berbeda dengan produk pesaing.

2. Untuk menarik perhatian, warna terang atau cerah kanmemantulkan cahaya lebih jauh dibandingkan dengan warnagelap.

3. Untuk menimbulkan pengaruh, misalnya untuk meningkatkanselera konsumen terhadap produk makanan.

4. Untuk mengembangkan asosiasi tertentu terhadap produknya.

5. Untuk menciptakan suatu citra dalam mengembangkanproduknya.

6. Untuk menghiasi produk.

7. Untuk memastikan keterbacaan yang maksimum dalampenggunaan warna kontras.

8. Untuk mendorong tindakan.

9. Untuk proteksi terhadap cahaya yang membahayakan.

10.Untuk mengendalikan temperatur barang didalamnya.

11.Untuk membangkitkan minat dalam mode.

Bentuk kemasan disesuaikan dengan produknya pertimbanganyang digunakan adalah pertimbangan mekanis, kondisi penjualan,perkembangan penjualan, pemejangan dan cara-cara penggunaan kemasan tersebut.

1. Bentuk yang sederhana lebih disukai daripada yang rumit

2. Bentuk yang teratur memiliki daya tarik lebih

3. Bentuk harus seimbang agar menyenangkan

4. Bentuk bujur sangkar lebih disukai dari pada persegi panjang

5. Bentuk cembung lebih disukai daripada bentuk cekung

6. Bentuk bulat lebih disukai wanita, sedang pria lebih menyukai bentuk siku

7. Bentuk harus mudah terlihat bila dipandang dari jauh.

Tanda-tanda identifikasi seperti merek dengan logo perusahaanadalah meningkatkan daya tarik konsumen. Merek atau logo ini berperan sebagai Brand Image sehingga dipandang dapat menaikkan gengsi atau status seorang pembeli. Syarat-syarat logo yang baik adalah :

1. Mengandung keaslian

2. Mudah dibaca atau di ucapkan

3. Mudah di ingat

4. Sederhana dan ringkas

5. Tidak mengandung konotasi yang negative

6. Tidak sulit digambarkan

\section{d. Ilustrasi}

Merupakan alat komunikasi sebuah kemasan bahasa universalyang dapat menembus rintangan perbedaaan 
bahasa. Ilustrasi initermasuk fotografi dan gambargambar untuk menarik konsumen.

e. Tipografi

Tipografi adalah teks pada kemasan yang berupa pesanpesan kitauntuk menjelaskan produk yang di tawarkan sekaligusmenyerahkan konsumen untuk bersikap dan bertindak sesuaidengan harapan produsen.

Beberapa hal yang harus diperhatikan dalam membuat desain kemasan :

\section{Lakukan Survey}

Lakukan survey untuk mengenal konsep desain kompetitor, seberapa pengaruh desain kompetitor terhadap penjualan produk. Buat Panelis dan poling untuk mengetahui sebarapa kuat kompetisi antara konsep desain produk anda dengan kompetitor. Dari hasil survey ini desainer akan mampu menciptakan konsep desain kemasan yang bisa bersaing.

2. Buat konsepdesain kemasan dalam beberapa alternatif.

Buatlah minimal 2 konsep desain kemasan sebagai bahan perbandingan antar dua konsep desain yang telah dibuat. Pilihan terbanyak terhadap salah satu konsep menjadi indikasi karakter konsumen terhadap produk yang akan dikemas nantinya.

3. Ciptakan desain kemasan yang unik dan menarik dan berkarakter

Usahakan untuk menciptakan desain kemasan produk yang belum dipakai oleh produk lain. Sehingga produk yang ditawarkan memberikan kesan lebih menarik dan lebih unik dibandingkan produk lain dengan jenis usaha yang sama.

4. Sesuaikan desain kemasan dengan isi produk Desain kemasan yang dirancang selayaknya harus mengacu kepada jenis dan karakter produk yang akan dikemas. Sehingga jangan sampai terjadi desain kemasan tidak memberikan corak produknya. Misal, desain sabun mandi tentunya berbeda dengan konsep desain pelumas mesin motor, sehingga kewajiban desainer memperkuat persepsi ini.

5. Sesuaikan desain kemasan dengan karakter konsumen

Seorang desainer kemasan harus pandai menganalisa kelompok segmen produk yang akan dikemas sehingga acuan hebatnya sebuat desain kemasan bukan hanya pada bagus atau tidaknya dari sisi grafisnya, tapi bagaimana desain yang diciptakan tersebut selaras dengan sasaran pasar yang dibidik, sehingga calon konsumen tidak merasa asing dengan desain kemasan yang dibuat. Membuat desain kemasan produk sesuai dengan target pasarnya, bisa dibedakan berdasarkan umur konsumen, maupun jenis kelamin konsumen, kelas harga penjualan, dan budaya daerah.

Adapun ringkasan dari materi yang diberikan kepada masyarakat diberikan dalam bentuk modul kit dengan isi:

1. Latar Belakang dan Tujuan Pengabdian Masyarakat

2. Garis besar tentang keilmuan Desain Komunikasi Visual khususnya kemasan

3. Contoh-contoh penerapan kemasan

4. Aplikasi keilmuan kemasan dalam kehidupan masyarakat

5. Pengertian, prinsip, dan metode pembuatan kemasan

6. Workshop pembuatan kemasan

7. Penutup

\section{Pengembangan Produk}

Tuntutan utama dalam kegiatan ini adalah menghasilkan sebuah produk yang dapat meningkatkan penghasilan peserta pelatihan dalam waktu yang relative tidak terlalu panjang, dan dengan menggunakan modal yang tidak terlalu besar (seminim mungkin). Artinya para peserta haruslah dapat menghasilkan sebuah produk yang mudah terjual, mudah diproduksi, dan terbuat dari bahan baku yang banyak tersedia disekitar mereka.

Dengan pertimbangan diatas maka pelatihan difokuskan untuk membuat sebuah produk sederhana yang mudah terjual serta memiliki permintaan pasar yang sifatnya stabil. Bentuk aktual dari produk yang direkomendasikan pada pelatihan ini terdiri dari dua jenis produk, yang pertama adalah produk yang memiliki fungsi praktis, dan yang kedua adalah produk yang tidak memiliki fungsi praktis (hiasan) seperti terdapat dalam gambar 2,

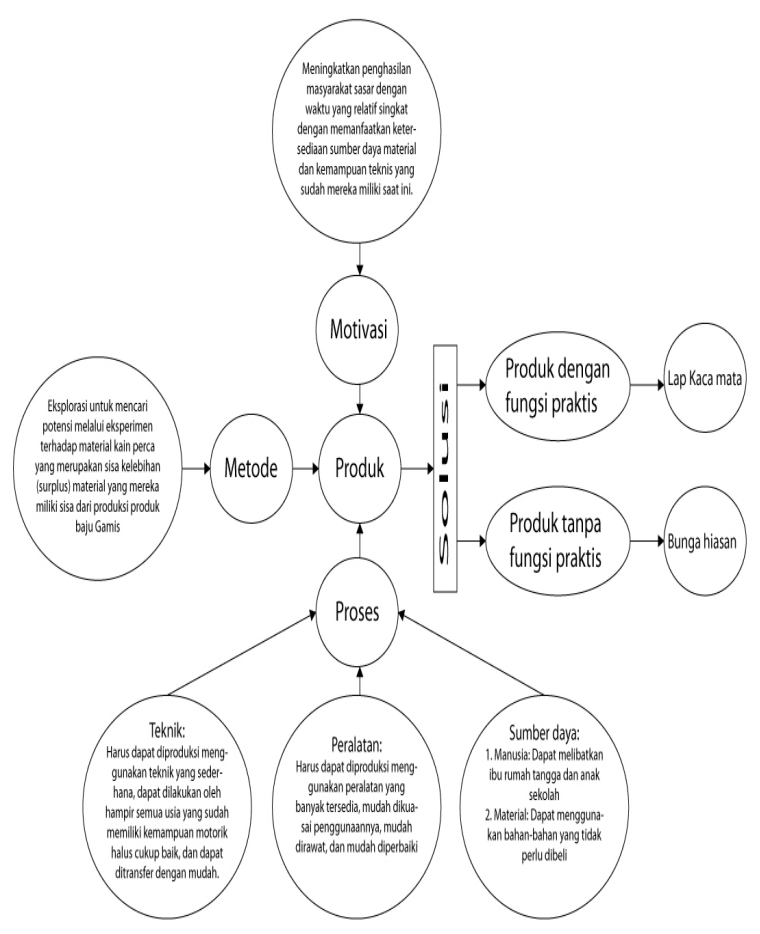

Gambar 2. Diagram pengembangan produk terpilih

Dalam pengembangan kemasan produk yang tidak hanya menghasilkan memperhatikan pada pembuatan kemasan, namun juga menyertakan kemasan baru yang telah dikembangkan, seperti terurai dalam tabel 2 . 
Tabel 2. Kondisi Dan Solusi Produk

\begin{tabular}{|c|c|c|c|}
\hline No & $\begin{array}{l}\text { Pertimbangan Desain } \\
\text { (Design Considerations) }\end{array}$ & $\begin{array}{c}\text { Kebutuhan desain } \\
\text { (Design Requirements) }\end{array}$ & Solusi \\
\hline 1 & $\begin{array}{l}\text { Motivasi: } \\
\text { Meningkatkan penghasilan masyarakat sasar dengan } \\
\text { waktu yang relatif singkat dengan memanfaatkan } \\
\text { ketersediaan sumber daya material dan kemampuan } \\
\text { teknis yang sudah mereka miliki saat ini. }\end{array}$ & $\begin{array}{l}\text { - Harus mudah dijual } \\
\text { - Harus mudah diproduksi } \\
\text { - Harus diproduksi dengan murah }\end{array}$ & $\begin{array}{l}\text { 1. produk yang memiliki } \\
\text { fungsi praktis berupa: Lap } \\
\text { kaca mata } \\
\text { 2. Produk yang tidak memiliki } \\
\text { fungsi praktis berupa: hiasan }\end{array}$ \\
\hline 2 & $\begin{array}{l}\text { Kondisi material: } \\
\text { Terdapat banyak sekali kain perca hasil kelebihan } \\
\text { sisa produksi baju gamis yang merupakan produk } \\
\text { utama masyarakat sasar, dengan jenis polyester } \\
\text { dan cotton, dalam ukuran rata-rata } 5 \times 5 \mathrm{~cm} \text { s } / \mathrm{d} \\
30 \times 30 \mathrm{~cm} \text {. }\end{array}$ & $\begin{array}{l}\text { Harus dapat memanfaatkan material kain perca } \\
\text { yang merupakan sisa kelebihan (surplus) material } \\
\text { yang mereka miliki sisa dari produksi produk baju } \\
\text { Gamis. }\end{array}$ & bunga \\
\hline 3 & $\begin{array}{l}\text { Kondisi Teknik: } \\
\text { Masyarakat sasar memiliki kemampuan dasar } \\
\text { teknik menjahit, pernah sekolah dan memiliki } \\
\text { kemampuan motorik kasar dan halus baik. } \\
\text { Kondisi Peralatan: } \\
\text { Sebagai sentra pembuatan baju gamis, } \\
\text { peralatan mesin jahit merupakan peralatan } \\
\text { yang banyak terdapat di lokasi }\end{array}$ & $\begin{array}{l}\text { Teknik: Harus dapat diproduksi menggunakan teknik } \\
\text { yang sederhana, dapat dilakukan oleh hampir semua } \\
\text { usia yang sudah memiliki kemampuan motorik halus } \\
\text { cukup baik, dan dapat ditransfer dengan mudah. } \\
\text { Peralatan: Harus dapat diproduksi menggunakan } \\
\text { peralatan yang banyak tersedia, mudah dikuasai } \\
\text { penggunaannya, mudah dirawat, dan mudah diperbaiki } \\
\text { Sumber daya: } \\
\text { 1. Manusia: Dapat melibatkan ibu rumah tangga dan } \\
\text { anak sekolah } \\
\text { 2. Material: Dapat menggunakan bahan-bahan yang } \\
\text { tidak perlu dibeli }\end{array}$ & \\
\hline
\end{tabular}

\section{SIMPULAN}

Solusi untuk mengatasi permasalahan yang terdapat di desa Kramat Mulya Kabupaten Soreang sebagai masyarakat sasar dari kegiatan ini dapat disimpulkan terbagi menjadi dua (2). Hasil pelaksanaan kegiatan pengabdian kepada masyarakat ini dilakukan berbagai pemecahan masalah sebagai berikut:

a. Memberi pemahaman mengenai kewirausahaan sebagai modal awal dalam mengembangkan usaha. Bentuk kegiatannya adalah pelatihan motivasi berusaha dan kewirausahaan. Salah satu contoh pelatihan untuk memberikan pemahaman dan motivasi kewirausahaan adalah dengan memberikan Pelatihan meningkatkan kreativitas dan inovasi dengan pemanfaatan teknologi dengan luaran berupa 1 jenis produk kerajinan tangan dan 1 buku saku

b. Mengembangkan usaha ekonomi produktif dalam bentuk Kelompok Usaha Bersama yang didasarkan pada potensi kelompok di antaranya adalah pemberian produk; Pelatihan pengolahan material buangan dari usaha jahit menjadi produk baru; Program pelatihan desain kemasan untuk produk industri jahit rumahan dan industri makanan ringan yang dilakukan oleh masyarakat sasar dengan luaran berupa produk kemasan untuk 3 usaha yang dilakukan oleh masyarakat sasar.

\section{UCAPAN TERIMAKASIH}

Ucapan terima kasih dan penghargaan yang setinggitingginya untuk Dinas Sosial Provinsi Jabar sebagai mitra dalam kegiatan pengabdian kepada masyarakat ini. Dalam pelaksanaan kegiatan pengabdian pada masyarakat ini Dinas Sosial Prov Jawa Barat saling melengkapi dengan dosen pelaksana kegiatan pengabdian pada masyarakat yang merupakan akademisi di perguruan tinggi dengan Tri Dharma yang dimilikinya

\section{DAFTAR PUSTAKA}

Fisher, T. (2010) Designing for re-use : the life of consumer packaging, Earthscan,London,. ISBN: 978-184407-487-7

Klimchuk, M and Krasovec, S A. (2012) PACKAGING DESIGN: Successful Product Branding from Concept to Shelf, John Wiley \& Sons, Inc., Hoboken, New Jersey. ISBN 978-1-118-02706-6

Klimchuk, M dan Krasovec S A. (2006). Desain Kemasan. Jakarta: Erlangga.

Kotler dan Keller. (2009). Manajemen Pemasaran. Jilid I. Edisi ke 13. Jakarta: Erlangga.

Kotler, P. (1999). Manajemen Pemasaran. Jilid II. Edisi Milenium. Jakarta: Prenhallindo.

Louw, A. \& Kimber, M. (2007). The Power of Packaging, The Customer Equity Company

Rangkuti, F.(2005). Analisis SWOT: Teknik Membedah Kasus Bisnis. Jakarta: Gramedia.

Simamora, B. (2007). Panduan Riset dan Perilaku Konsumen. Jakarta: Gramedia.

Louw, A. \& Kimber, M. (2007). The Power of Packaging, The Customer Equity Company. 